\title{
Google Me This: What Can Project Management Be for Libraries in the Age of Google et al.?
}

\author{
Cătălina Rojịsteanu \\ National Military Library, Bucharest \\ E-mail catalinarojisteanu@yahoo.com
}

Given the challenges the libraries are facing in pursuit of adapting to the changes of the new century's information and communication revolution, using project management as proficiency instrument for taming these challenges can be beneficial for libraries. This article abridgedly presents the key theoretical aspects of project management, the state of affair of foreign libraries using project management as seen in the specialized scientific literature from the last few years, and, last, but not least, an attempt to establish the degree of use of project management in Romanian libraries at the moment of 2015 by the means of an interview guide and a netnographical research of one of the Romanian professional online platforms, Biblos [1]. Even though the results of the interview and the netnographic research have not met the expected results, the data revealed a certain status quo of the relationship the Romanian professional community has with project management culture.

Keywords: libraries; project management; library users; change; projects; Biblos; netnography

\section{Introduction}

\subsection{New roles for libraries}

Irrespective of their national, special, public, or educational character, libraries are organizations that share the same functions and technical activities. Their core competency is to provide free access to information for their users. Drucker (1986 p. 118) considers that libraries offer the community a public good "which otherwise could not have been offered - often at the most prohibitive price - but in a collective way". In 1979, Michael E. Porter, an American professor at Harvard Business School, defined a useful strategic tool - the analysis of the five competitive forces (competitive rivalry, threat of new entrants, threat of substitutes, bargaining power of suppliers, bargaining power of customers) which shape the strategy of a company. Although the five forces analysis is widely used in the economic sector, such an instrument can also be useful for shaping a library strategy, especially by identifying these competitive forces, even if the competition aspect is hardly seen in this cultural/educational area where co-operation and information sharing are key words. It is most likely that libraries from the same or different fields collaborate and exchange information in the benefit of their users, rather than compete to attract each other's customers. Other factor with medium or low influence is the relationship between libraries and their suppliers. This relationship is sometimes established by law (such as the case of Copyright Law), and is very restrictive due to the financial constraints (in the vast majority of cases, libraries' budgets come from mother-institutions and are not subject to changes or negotiation). The threat of new entrants also seemed almost non-existent, especially due to the fact that the wide majority of existing libraries have been established for decades. New information centers which might be opened in the future will only add information value to the existing market.

However, the recent years have witnessed the emergence of new niche-typed of libraries (a subject

Revista Română de Biblioteconomie şi Ştiința Informării = Romanian Journal of Library and Information Science ISSN 2559-5490, ISSN-L 1841-1940 • Volume 13 Issue 22017 pp. 27-46 https://doi.org/10.26660/rrbsi.2017.13.2.27

This work is licensed under a Creative Commons Attribution-NonCommercial-NoDerivatives 4.0 International License 
of further investigation). They are private-owned libraries and they address the needs of that particular category of library users which are the least frequent users, the 25-60 years old who do not have the time to go to the library and are not aware of the services offered by the public system libraries. They function in the form of anticafés or as subscription libraries. The concept of anticafé was developed in 2011 by Ivan Mitin who opened in Moscow the Ziferblat Anticafé, a place where the consumers buy time and get a quiet place to work, to study and to have a coffee. The anticafé became a concept, "a social and cultural epicenter". In Bucharest, Seneca Anticafé is a café/tee house and a library/space for work, study, meetings and cultural events. Another example of niche library is Bookster, the "corporatist's library", a Romanian start-up which function as a subscription library and which delivers books, articles, audiobooks and video materials (e.g. Ted presentations) directly at the users' offices.

The highest threat for libraries comes from their most important substitute: the Internet. Libraries seemed to have no competition for the services provided. Internet is definitely such a rival, and the problem is not to fight the enemy, but to co-operate and to promote the advantages of using the library services, and to use the online medium to share information, to promote the services, to communicate inside and outside the organization. Libraries can also tame the Internet beast by using their resources to put some order into the apparently chaotic Internet information. Other substitutes can be bookshops or mass-media, but since the free aspect of access to information was taken into consideration, these substitutes were left aside. Last, but not the least, there is the library user. Although the customers do not pose a threat to libraries, they are of great influence. As with any other business, the libraries' mission, objectives and strategies should revolve around their users. Drucker, cited by Stueart and Moran (2007 p. 17), suggests that libraries should "focus on mission, demonstrate accountability, and achieve results" by self-assessing their mission, their user, their user values, their results and their plans.

In the 90' three Danish theoreticians, Jochumsen, Skot-Hansen and Rasmussen (2012), proposed a model of a library composed of four representative spaces:

1. Cultural centre

2. Knowledge centre

3. Social centre

4. Information centre.

Their main idea was that the Internet and the new communication and information technologies have not killed the library, but have contributed to its transformation. People keep coming to the library, but they are granting it new values and capabilities. At the international level there is a tendency to move the accent from book collection and storage to connectivity and creativity, to the idea that the library is a place which inspires creativity and innovation, facilitates cultural communication by the means of exhibitions and events created by the users themselves, a place which offers its users the necessary tools for involving in the life of the community. In order to adapt to the new environment, the library reconfigures its spaces not only to make room for the new communication and information technologies and devices, but also to redesign its services by making them more attractive.

The mission of a library can be defined only if the users and the environment are known. Libraries serve a community of users. They are individuals with different informational needs. As well, the library functions in an electronic/virtual/digital world whose characteristics are permanent feverish change, speed, the disappearance of time and space barriers, 24/7 availability of decentralized and globalized services. On the other hand, the developments in communication and information technologies have led to the emergence of communication devices which present two big advantages: they are relatively cheap and easy to use. They have also led to permanent changes in human behavior.

Social media, these virtual spaces for sharing personal or professional information, have become 
part of everyday life. Various statistics outline the fact that these social media are big time consumers, and the data are astonishing. For example, on May $9^{\text {th }} 2017$, there were way more than 3 billion Internet Users, over 1 billion websites, over 185 billion emails, approximately 5 billion videos on YouTube, over 4 billion Google searches, approximately 4 million blog posts. Meanwhile, Encyclopedia Britannica has ended its printed edition after 244 years of existence. Likewise, an OCLC report issued in 2005 stated that $84 \%$ of library users initiate an information search using an Internet search engine and only 1\% initiates the search on the library's web page. A similar report issued by OCLC in 2010 stated that nobody starts the information search on the library's web page.

At this point, a library user faces a dilemma. In search of his information, he/she must choose between two options. He/she can go to the library where he/she can obtain the information free of charge, but he/she must consume time and leave home/office. Or he/she can search the information on the Internet at the comfort of his/her home anytime. Here, there are two more options: either the information is relevant or irrelevant (authoritative or lacking authority), or the information is free of charge or he/she must pay to obtain it. (I have put myself in the library user's shoes. In search for information for this paper, due to the lack of time and in need of convenience, I have decided to search and obtain my information on the Internet using the Google search engine. I have found a decent amount of free and authoritative information - articles or chapters of books in PDF format which had many citations. The downside of my choice was the fact that I had to leave aside the paid articles, for my experiment required only free information).

Dependent upon bigger organizations in terms of financing and policing, and acting in a non-profit area, one might say that libraries are situated outside the competencies of management. They have well-established roles in society, everybody knows what it is all about, and as long as the libraries are doing their things right, everything will be OK. Still, in our world of turmoil, the emerging question for any organization to ask itself is: "Are we doing the right thing?"

Change is therefore imminent for libraries. It is not the purpose of this paper to deal with the impact of change on organizational culture, but to find ways to manage it. Anzalone (2000 p. 57) considers that "project management is an ideal tool for service organizations to use to respond to change quickly". As well, Langley (2013 p. 2) considers that "every strategic initiative is essentially a project or program, and that all strategic change in an organization occurs through projects and programs".

One useful place to find the drivers of change in library services is the mission and vision statements and documents of various libraries around the world. The analyzed documents have several elements in common:

- They are written using specialized project management terminology, in terms of goals, objectives, deliverables, stakeholders, projects, evaluation, etc.

- They outline the same roles for libraries for the future: learning hub, community enhancer, economy support, access provider.

- They speak mostly about innovation and transformation which they consider to be the main drivers for change.

- They imply the necessity of new skill for future librarian, including project management knowledge.

- They have been developed as projects.

Out of the documents I have analyzed, The Library of Congress' document entitled "Strategic Plan. Fiscal Year 2011-2016" is the most complete, containing vision and mission statements, objectives, strategies, and values. The vision derives from "The Librarian's Letter" which is more than an introduction written by the Library's Manager: "We aim to sustain this level of value and excellence... The vibrant and forward-locking spirit and the dedicated stewardship of the Library's staff shine a bright light on America's oldest federal cultural institution". The mission is focused 
on the Library of Congress historic competency. The strategic goals are presented from the points of view of public benefit, outcomes and results, and strategies. In comparison, the National Library of Romania includes its vision, mission and strategies in a retrospective document published on its web site: "Raport anual de activitate - 2013" [Activity Report 2013] (Biblioteca Națională a României, 2013). This report also includes a PESTEL and a SWOT analysis.

The most obvious difference between the foreign and the Romanian documents is their character: the foreign ones are proactive, and the Romanian ones are passive. The first ones are focusing on "attractive futures and unreachable dreams". The last ones focus on processes and activities. While the users and the staff are very present in the foreign libraries' plans, it is hard to notice them in the Romanian libraries' documents.

As well, a study conducted in 2013 in libraries from Europe and America regarding the vision of the library's role and the message that the library building should transmit outlines the iconic character of the building, the cultural, artistic and educational aspect of that mission, the concept of a nonconformist space and vivid community center.

\section{2 "Project as a unit of work"}

Across literature there are many definitions of project and project management, almost all reinterpretations or paraphrases of the Project Management Institution's definition.

According to Project Management Institute, cited (among many others) by KPMG Project Management Survey Report (2013 p. 5),

"a project is a temporary group activity designed to produce a unique product, service or result. A project is temporary in that it has a defined beginning and end in time, and therefore defined scope and resources. A project is unique in that it is not a routine operation, but a specific set of operations designed to accomplish a singular goal'.

It is not the purpose of this paper to further present, nor to analyze the particular issues of project management, but to outline its benefits for the success of and control over library's initiatives.

There are two types of factors which lead to change: internal and external factors related to an organization. As far as the libraries are concerned, the external factors are closely related to the revolution in the realm of communication and information technology and to the impact of this revolution on the behavior, prospects and informational needs of the library users. Stueart and Moran (2007 p. 45) considers that the internal factors are related to aspects such as the necessity to improve librarians' skills, "ethical and social responsibility and the desire to work in teams, (...) applying different theories and practices in the field of managing the library and information services" Libraries need to adapt to the changes driven by these external and internal factors. It is also imperative that they improve or replace their tools, their structures, their services and their stand. The necessity to adapt to change is visible in librarianship through an orientation towards a new type of organization: knowledge based and project oriented. Recent librarianship literature outlines the project orientation in concern to library's services. There are many transformations a library can conduct in the form of a project:

Building projects

Relocating projects

IT infrastructure modernization projects

Library website development

Collection digitization projects

Introduction of a new service to users

Inter-institutional projects

Institutional repositories

Platforms for mobile devices 
Gareis (2006 p. 19) considers that the main advantage of approaching an initiative as a project and using formal project management methodologies is a "way to ensure the specific quality of results".

This approach offers library managers tools and methods which can ensure the specific quality of the outcomes by dividing the whole into sub-processes which can be well defined, well attributed, quantified and controlled.

Irrespective of their type, library projects are managed by the means of project management well documented methodologies. From this point of view, dividing the project into standard subprocesses - as Gareis (2006 p. 60) enumerates them: "starting the project, coordinating the developing project, controlling and closing the project"- is a way of unequivocally comprising all project elements: "the objectives, the outcomes, the deadlines, the costs, the profit, the risks, the organization, the culture and the context of a project" (Gareis, 2006 p. 143).

Analyzing the technical, social, economical and political influences on a project, Harpham (2004 p. 153) considers that "depending on the nature of the project, of its location, destination and objectives, of its owner and strategy chosen for the project, the impact of each of these contexts of the projects can vary significantly". Therefore, before launching a project, feasibility studies are conducted. As Simister (2004 p. 442) states, this helps "examining the possible option range and identifying potential problems". In the same time, studies which analyze the role of the library within its community and studies for analyzing the political, economical, social, technological, legal and environmental context are accomplished.

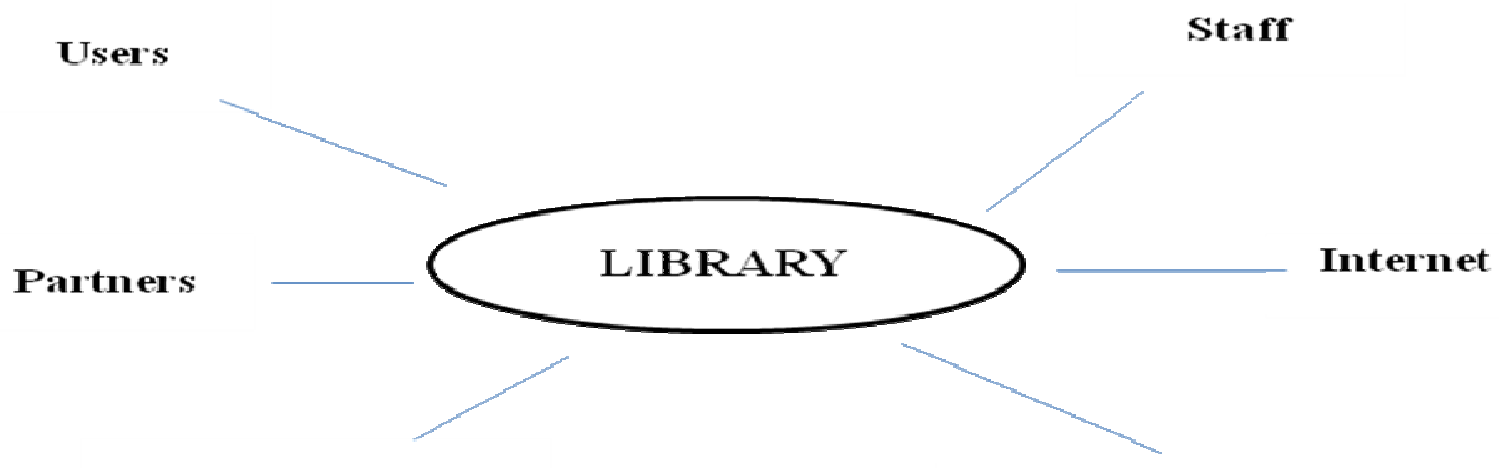

Mother-institutions

Regulating bodies

Figure 1. Contexts for library projects

After analyzing the feasibility studies and thoroughly analyzing the stakeholders and the context of the project, the decision to start the project can be taken. The first stage is to designate a project manager and a project management team who share responsibilities of the project. Further on the project scope is defined, but as Simister (2004 p. 219) notes, a clear and accurate definition "plays the role of an evaluation standard of measure". All the information established until this point must be included in the project initiation document (or project charter). The next stages in managing a project are: defining the content of the project and organizing the activities in a break-down structure, specifying the resources, planning the project by establishing milestones and an execution chart, controlling and monitoring the project according to the milestones and execution charts, updating the plans according to the project evolution, and after closure, evaluating and auditing the project and the project management team members.

One very important aspect which needs to be taken into consideration from the very beginning is the importance of proper defining the term project as opposed to the term service. Reviewing an organization's project work can help establish the difference between service and project, as Vinopal (p. 385) said, "by confusing projects (which have a defined end date) with services (which 
are ongoing), we were internalizing the mistaken idea that projects never end".

Besides the triple constraint of time, costs and scope, a project is also defined by the human resources, risks and by the concept of quality. To approach a new activity/idea as a project and to manage it by the means of formal and standardized methodologies is a way of ensuring the existence of quantifiable indicators that can measure the success of a project. Nevertheless, it is essential that all the stakeholders involved in the project are aware and agree upon these evaluation criteria. Zarinpoush (2006 p. IV) stated that the evaluation of a project is considered to be "a systemic investigation of the value or signification of an object". The aim of an evaluation is to verify by the means of specific tools the implementation of the project according to the triple constraint. An exact interpretation of the evaluation data can help the project manager make the proper adjustment (if the evaluation is performed interim), and also the evaluation data can offer information about the impact of the outcomes and can be the basis of the lessons learned database of the organization for future reference.

The project manager in a library project can be either a representative of the library (the manager, another member of the staff), or a professional from the outside (although the case studies analyzed in the literature suggest that the project manager for library project is usually a staff member). The main qualities of a project manager are to be a binding agent of his/hers team, to be a good coordinator of the specific project management activities, to have strong communication skills. Moreover, a project manager of a library project should know the role and the mission of his/hers library and needs to be trusted by the staff.

The best results appear when all the stakeholders are involved throughout the whole project implementation. The stakeholders are those persons or organizations which have an interest in the project and whose actions can influence, positively or negatively, the project outcomes. In regard to library projects the following stakeholders can be identified: the library manager, the library staff, representatives of the mother institutions, representatives of the users' community (depending on the library type), representatives of public administration, business organizations, cultural organizations, mass media. First of all, these persons or organizations must be extensively analyzed so that their interests are well described and known. Then, the project management team must come up with solutions and measures which need to lead to improving the relationship with the stakeholders. Essential to the success of the project is collaboration with the stakeholders and a continuous and honest communication with the stakeholders.

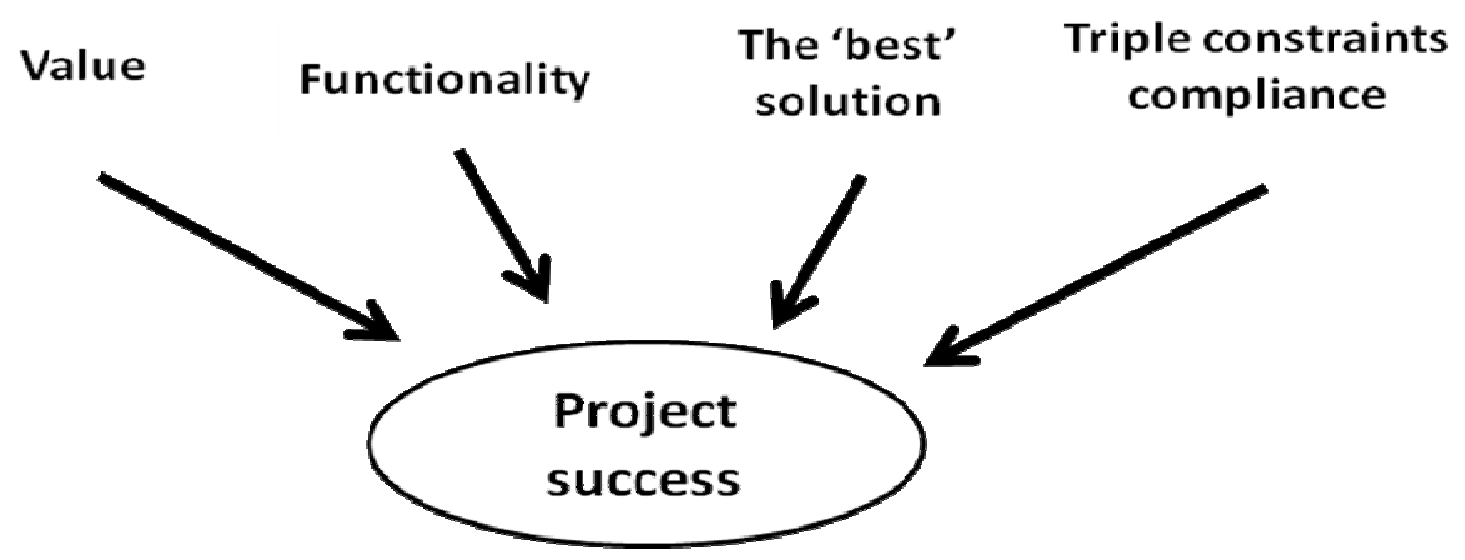

Figure 2. Main success criteria for projects 
It is difficult to establish a success template for library projects especially due to the fact that the library is a cultural institution anchored in the needs of its community. In the case of a building/ redesign project, IFLA (International Federation of Library Association) has issued a questionnaire for evaluating both the initial expectations before the project start, and the outcomes of commissioning the new building. This questionnaire comprises questions about the location, the sustainability of the building, the interior design aspects, the functional aspects of the building (acoustics, furniture, ventilation systems etc.), the spaces designed for the users, the spaces designed for library staff. "The purpose of this questionnaire is to allow the library managers and the project team to identify good practices, to learn from their mistakes and to send back into the system the lessons learned so that the future generations of library constructions to continue to stand for excellence in design and functionality".

Horwath (2012) has conducted a review of the librarianship literature on the project management topic. While noticing that, at that moment, there were few articles on project management in libraries, Horwath discovered that the articles covered three aspects: case studies of particular projects implemented by (mostly) academic libraries, general presentations of project management processes and methodologies, and the issue of the skills project management requires for librarians. Horwath also presented the results of an online survey conducted among Ontario library staff, as well as of interviews with library managers from the region on the project management topic. The author notices the informality of the approach towards managing projects, "with only a few libraries employing mature strategies with formal approaches such as consistent use of templates and forms and a PM infrastructure that supports monitoring and controlling throughout the project life cycle".

One article that can be included in the second category is written by Atkins (2004 p. 7-9). She analyzed two projects implemented by the University of Illinois Library: the barcoding initiative (completed at the moment of the article) and a high density shelving facility (still in the implementation phase). Atkins highlights five aspects of successfully managing projects which can be considered as good practices:

- using experienced team members with suitable skills,

- thoroughly planning the process so that the project team can stick to the initial plan,

- "achieving balance between planning and flexibility",

- communication and stakeholders' management, and

- using project management software as a tool.

Atkins concluded that the projects were successful due to using formal project management methodologies, especially if one takes into consideration the fact that the projects were undertaken during periods of financial constraints.

The majority of the articles on library projects focus on case studies of projects implemented by various types of libraries especially in the realm of collection digitization. Digitization projects are characterized by several aspects. Not only they entail huge effort and vast amounts of resources, but at the same time, they need to take into account two issues which are out of control: the rapid development of information technology and communication devices, and the needs of born digital people (also called digital natives). One of the recurrent ideas of these articles is that the main driver for adopting formal project management methodologies is the failure of previous projects due to the lack of a formalized approach.

Another aspect worth taking into consideration is what PMI considers to be the "tailoring" of the project management methodologies. Whitaker (p. 4) considers that "a project management methodology should reflect the size, duration and complexity of each individual project, and be adapted to the industry, organizational culture and level of organizational project management maturity of the organization". 
For example, Kate Zwaard and David Brunton, supervisory IT specialists in the Library of Congress Repository Development Center, wrote on the Library of Congress blog that "the 'project' is our unit of management". They tailored the methodologies used for managing their projects so that they suit their needs. They simplified the formalized approach and use the project charted as "the only required project document". As well, they had not invested in expensive software, but decided to use "free and open source software extensively". They paid attention to complying with time and budget constraints by segmenting bigger projects into smaller ones and by "working incrementally". They communicated every aspect regarding the projects not only among the team members, but to the stakeholders which in turn leads to member commitment and to stakeholder involvement.

When introducing project management methodologies in libraries, one needs to take into consideration also the organizational and human aspects of the matter. Librarians need new skills in order to be able to deal with the projects they are undertaking. Libraries do not have to reinvent the wheel, neither to create new departments or complex infrastructure for project management. They can build on the existing structure. As for the skills, most libraries either train their staff on a regular basis on project management skills, or use the lessons learned as a basis for training. As well, the curricula of masters' degree in librarianship across the world offer classes on project management for librarians. Kinkus (2007 p. 357) presented the data of a survey conducted in 2003 among 47 ALA (American Library Association)-accredited master's degree programs: "of the 26 replies that were received, 21 library science programs reported that at least one course in their library science master's curriculum addressed project management".

We can conclude that there are important benefits of project management to organizations:

- Control over decisions

- Standardization of processes

- Clear definition of scope

- Staff responsibility

- Flexibility in managing stakeholders

- Segmentation of work which leads to focus, efficiency and effectiveness.

However, as Horwath (2012 p. 2) concludes, "the growth of projects in libraries is pervasive". The growing number of projects imposed a need to keep them under control in order to further optimize an organization's resources and to ensure the successful completion of the projects. This is the reason for which a specialized department in charge of managing an organization's projects (and programs) portfolio was developed, and it is known as the Project Management Office (PMO). Bonghez (2013 p. 49) attributes to a PMO double major characteristics: consistency in project implementation and alignment to organizational strategy. PMI considers that "PMOs help:

- Reduce failed projects

- Deliver projects under budget

- Improve productivity

- Deliver projects ahead of schedule

- Increase cost savings".

Vinopal (2012 p. 379-385) makes a case for introduction of project portfolio management for academic libraries: "Project portfolio management provides a way to ensure that this project work supports the organization's strategic vision, the active projects represent the highest priorities of the organization, and there are enough resources to accomplish all the project work at hand". Project Portfolio Management is to be considered "a performance assessment tool", a tool which allows project managers to have control over their projects, to have available a lessons learned inventory that helps them unravel the over-scheduling work and cost overrunning, track modifications, provide solutions, and help prioritization of organization's projects. "Just as the goal of project management is to increase productivity and effectiveness at the project level, 
project portfolio management is designed to increase efficiency at the organizational level". Another advantage of this tool is that it acts as an informal extrinsic motivator because it "gives staff public credit for the work that they are doing".

The next logical step for an organization which develops new products and services via projects and which has adopted the PMO is to become project-oriented. According to Gareis (2006 p. 25), a project-oriented organization is the organization which "implements projects and programs in order to achieve comprehensive and relatively unique business processes". Besides flexibility, better definition of organization goals and attractiveness of work due to the challenging environment which fosters creativity, another advantage of project oriented organizations is that the lessons learned contribute to the on-going on the spot training of project team members. A report of PMI (2015 p. 13) states that "from capturing and sharing lessons learned to easing the impact of losing experienced staff, knowledge transfer represents a critical - but often undervalued - organizational competence". Unlike business organizations, library project teams are comprised of librarians, less often from outside contractors. Thus, it is easier to capture and communicate knowledge on projects.

Bonghez et al (2012) have conducted a research in the attempt to establish the project management maturity level of small and medium enterprises from Romania. Her hypothesis was that "that project management is not among the strategic priorities" of the Romanian SMEs, thus their project management maturity level would turn out low. The proposed model measured the project management maturity of the following aspects: project management itself, the dimensions of project management process, the project portfolio management, the organizational design, the project personnel, and the participation in programs (program management). The results of her research validated her assumption. "This is where the power of project management can be seen, which, adopted at the organizational level, can provide the expected competitive advantage". In case of libraries which employ project management methodologies, auto-diagnosis or determining the maturity level can be a good starting point in order to identify strengths and weaknesses of project management in an organization.

\section{The Interview}

My first attempt in probing the findings of this paper was to conduct an interview. Babbie (2011 p. 291) defines interview as "a data-collection encounter in which one person (an interviewer) asks questions of another (a respondent)" with the purpose "of discovering underlying meanings and patterns of relationships". My assumption was that project management methodologies can help libraries face and address the challenges of the Internet age. I intend to demonstrate that the project management approach to library's activities and services is an efficient and effective way to insure not only the survival of libraries, but their revitalization.

My target were library project managers or members of project teams from Romania and abroad. Table 1 contains the librarians to which I have sent the interview guide.

I have chosen the interview participants as follows:

- In the case of the Romanian libraries, I have tried to cover both academic and public libraries. I have succeeded in obtaining the contacts via an informal way, from my colleagues from the Standardization Committee.

- In the case of foreign libraries, my intention was to contact the authors of the articles used for writing my paper, as their contact data was already written on the first page of their articles. My assumption was that, since they have made available their contact data, they would be available to answer some questions regarding a topic of their interest. 
Google Me This: What Can Project Management Be for Libraries in the Age of Google et al.?

\begin{tabular}{|c|c|c|c|c|}
\hline No. & Name/contact & Position & Institution & $\begin{array}{c}\text { Response } \\
\text { received }\end{array}$ \\
\hline 1. & Jenn Horwath & $\begin{array}{l}\text { Digital Services } \\
\text { Librarian/Project } \\
\text { Manager in Centre for } \\
\text { Teaching and Learning }\end{array}$ & $\begin{array}{l}\text { Mohawk College } \\
\text { Library }\end{array}$ & yes \\
\hline 2. & Maria Rodica Volovici & Library Director & $\begin{array}{l}\text { Lucian Blaga } \\
\text { University of Sibiu }\end{array}$ & yes \\
\hline 3. & Ovidiu Calugarescu & Library Director & $\begin{array}{l}\text { Library of National } \\
\text { University of Defense } \\
\text { 'Carol I' }\end{array}$ & yes \\
\hline 4. & Kathryn Mendenhall & $\begin{array}{l}\text { Acting Director } \\
\text { Partnership \& Outreach } \\
\text { Programs }\end{array}$ & $\begin{array}{l}\text { Library of Congress/ } \\
\text { Library Services }\end{array}$ & no \\
\hline 5. & Voichita Dragomir & IT Manager & $\begin{array}{l}\text { Central University } \\
\text { Library of Bucharest }\end{array}$ & no \\
\hline 6. & Cristina Albu & Library Manager & $\begin{array}{l}\text { Polytechnic } \\
\text { University Library of } \\
\text { Bucharest }\end{array}$ & no \\
\hline 7. & Agnes Erich & Library Manager & $\begin{array}{l}\text { Dambovita County } \\
\text { Library }\end{array}$ & no \\
\hline 8. & Stephanie Atkins & Unknown & $\begin{array}{l}\text { University of Illinois } \\
\text { Library }\end{array}$ & no \\
\hline 9. & Cynthia Basset & $\begin{array}{l}\text { Electronic Services } \\
\text { Librarian }\end{array}$ & $\begin{array}{l}\text { University of } \\
\text { Missouri Law School }\end{array}$ & no \\
\hline 10. & Resa Kerns & $\begin{array}{l}\text { Associate Law } \\
\text { Librarian }\end{array}$ & $\begin{array}{l}\text { University of } \\
\text { Missouri Law School }\end{array}$ & no \\
\hline 11. & Petra Duren & $\begin{array}{l}\text { Professor of } \\
\text { Librarianship }\end{array}$ & $\begin{array}{l}\text { Design, Media and } \\
\text { Information Faculty, } \\
\text { Hamburg }\end{array}$ & no \\
\hline 12. & Simon Bains & $\begin{array}{l}\text { Head of Research } \\
\text { Services and Deputy } \\
\text { Librarian }\end{array}$ & $\begin{array}{l}\text { University of } \\
\text { Manchester }\end{array}$ & no \\
\hline
\end{tabular}

Table 1. The librarians which received the interview guide

\subsection{Methodology}

For this research I have used the following interview guide:

1. Please describe in a few words your position and your library.

2. How do Internet, Google, open access online information impact the library services?

3. What projects has your library implemented? Please choose from the list below.

Building projects

Relocating projects

IT infrastructure modernization projects

Library website development

Collection digitization projects

Introduction of a new service to users 
Inter-institutional projects

Other (which one)

4. Have you used a structured project management approach to manage the projects?

5. If yes

a.To what extent do you consider that a structured project management approach contributes to the projects' success?

b. What are the success criteria for a library project?

c. What formal written project management methods (project charter, WBS etc.) did you use? d.How did you assign the members of the project team?

e.What was your relationship with the stakeholders during the implementation of the projects?

f.What were the challenges during implementation of the projects?

g.How did the implemented projects influence the library's activity?

h.What are the visible and less visible changes after implementing the projects?

i.How has the project management approach influenced the library's organizational culture (the way librarians work and behave)?

j. Have you previously trained your librarians so that they can acquire project management skills and knowledge?

k.How often do you train your librarians in the field of project management?

6. Do you have a designated department for your library projects or programs?

Thank you.

As it can be seen, I have used a structured interview guide with open ended questions, which bears an overall resemblance with a questionnaire survey. I have chosen to walk an easy path as the interviews would be conducted via email. I have selected this way of contacting my respondents because most of them were located abroad, and because I intended to go on with my experiment and make the most of the use of Internet. The downside was that email interviews might have a low response rate. Another disadvantage of conducting structured interviews via email is that the list of questions has a rigid character and that there might have been some words' confusions or misinterpretations which could not have been clarified at the answering moment. Moreover, the lack of face to face interaction is bound to lead to restrictive data and to hinder the collection of qualitative data which might have contributed to a deeper understanding of the phenomena.

However, there was one big advantage of conducting a structured interview: the coding for data interpretation was already done, and the patterns or themes were already established, thus, easing the analysis of the data.

\subsection{Results}

The interview guide has been sent via email to 12 librarians from Romania and abroad. As anticipated, the response rate was very low. Out of the $12^{\text {th }}$ requests, only three librarians have answered to my questions, while another three librarians from abroad declined to response invocating the lack of time, and two librarians from Romania informed me during an informal conversation that they do not feel able to answer. This makes the data collected neither valid, nor relevant for my research.

I can only guess the reasons for not receiving the responses. One reason is that interviews conducted via email do score a low response rate. Another reason might have been the fact that I gave the participants only two weeks to respond, which proved to be a very short period of time (as noticed before, three participants claimed they had not enough time to answer to my questions). In the case of Romania libraries, I can guess that the librarian either did not have time to answer, or they lacked the knowledge on the matter. One of the two Romanian librarians mentioned above claimed that their library does not work through projects, and the other one who 
was involved in writing a few European funded projects for her library, seemed puzzled about the questions.

However, the strange fact was that all three responses came from academic libraries, one from Canada, and two from Romania (Bucharest, and Sibiu). In the same time, my general impression after studying the literature on the matter is that academic libraries are more concerned with the project management issues than other types of libraries. If the articles about the projects of public libraries deal with the projects outcomes, the articles about the projects of the academic libraries deal more with project management methodologies in attempts to find ways to improve them and to assess the project management methodologies contribution to the projects' success.

Although I have admitted that this interview research can hardly be considered either relevant, or valid, I had analyzed the data from the three respondents. The overall idea is that the data confirm my assumption. All three librarians, one Canadian, and two Romanian, consider that project management methodologies helped their libraries face and address through projects the challenges of the Internet age. As well, their responses highlight the efficiency and effectiveness of project management approach to library's activities and services.

As mentioned above, they all work at academic libraries, the Romanian respondent being library managers, and the Canadian respondent working as librarian/project manager.

All respondents acknowledge the impact of Internet on library services, outlining the useful aspect of it, specifically the way Internet fostered the development of new services which contributed to enhancing library visibility among its users.

All three libraries have implemented projects, of which the relocation and IT modernization projects stand out.

In regard to using a structured project management approach, the Romanian librarians acknowledge using one, while the Canadian librarian considers they do not have that need because they undertake "small projects".

All respondents acknowledge the contribution of a structured project management approach to the projects' success, while defining success in terms of the triple constraint compliance. As well, one Romanian respondent has added as success criteria the need to develop new service according to the users' needs.

All respondents admit using formal written project management methods. One Romanian respondent has added to the enumeration in the brackets (see question no. $5 \mathrm{~b}$. from the Interview Guide) the lessons learned document.

The project team members are nominated similarly in the three cases, out from the library staff. One Romanian respondent outlines the existence of certain selection criteria: "willingness to participate, professional competence, adaptability, and flexibility".

All respondents admit having a good relationship with their stakeholders. (Note: it is possible that this question might have been formulated in a more explicit way, thus it could have attracted a more detailed answer regarding the relationship with the stakeholders.)

All respondents offered ample answers to the question relating to the challenges during implementation of the projects. In this case, their answers were very different, highlighting different challenges. For the Canadian librarian, the main challenges were "the underestimation of the project's complexity" and the limited time and personal resources. For one of the Romanian librarians, the main challenge was "the resistance to change" manifested by the team members. The other Romanian librarian highlighted a positive aspect of the challenges, i.e. the challenges allowed them to develop new solutions to problems.

All respondents acknowledged the major impact on their library's activities of the implemented projects. 
The question about the visible and less visible changes which occurred after the projects were implemented triggered ample and various responses. The Canadian librarian pointed out as visible the new skills acquired by the staff and the improvement of the services, and as less visible, the good team work and the sense of ownership. One of the Romanian librarians pointed out that the project management approach eased the daily work, while the other Romanian librarian outlined the users' satisfaction towards the new and improved library services as one important visible change.

All three respondents highlight one important and similar contribution of project management approach to the library's organizational culture: it helped enhance motivation among staff.

In regard to training the librarians in the field of project management, the responses differ: the Canadian librarians admitted that the librarians have not been previously trained, nor are they trained on regular basis; the Romanian librarians acknowledge both previously training, and regular training of their staff.

The last question regarded the existence of a designated department for library projects or programs. I have included this question because I was interested in the level of the development of their organizational structure. The existence of a designated department for library projects (also known as Project Management Office) can indicate the fact the project management approach has been assimilated by the organization. Out of the three responses, one Romanian library already has such a department, the other Romanian library intends to set one up, and the Canadian library does not have a designated department for library projects or programs.

\subsection{Discussion and conclusions}

The research has not accomplished its purpose. Even though the data collected might have confirmed my assumption, they could be considered neither valid, nor reliable. What I was able to obtain is only a hint, but not a valid state of the affair.

\section{Contingency Plan: A netnographical research attempt}

As a contingency plan made ad-hoc after realizing that the interview respondents might not answer my questions in due time, I have decided to join an online community for librarians in order to get in touch to their present concerns, to notice the presence or the absence of their concerns regarding project management, and to post my interview guide.

The concept of netnography and its tools and methodology have been defined by R. Kozinets, cited by Kulavuz-Onal, D., Vasquez, C. (2013 p. 225), as "an interpretative method to investigate the consumer behavior of cultures and communities present on the Internet". Although the online research methodology was initially designed for marketing and consumer research, it can be also employed in the study of the professional online communities.

\subsection{Methodology}

The communication server of "Mihai Eminescu" Central University Library from Iasi has hosted since March 31 $1^{\text {st }}, 1998$ a discussion list, Biblos, designed for librarians from all over the country.

In search of information about this discussion list I came across the name of Dan Stoica and an interview he gave in 2001. The Biblos discussion list is strongly connected to the name of Dan Stoica, former head of Computerization Department at the Central University Library, Iasi.

In an interview Robert Coravu took of Dan Stoica (Coravu\&Stoica, 2002), at that moment there were 98 members of Biblos, half of them being from university libraries. Robert Coravu also noted 
that the libraries present on the discussion list were from Bucharest and Timisoara, while the National Library of Romania seemed to be a discreet presence. Dan Stoica intended to create a forum for the librarians to exchange ideas, and information in order to reach a common understanding in the approach of certain professional issues. He thought that "even maintaining an irreducible position would have been a progress". At the moment of that interview, Dan Stoica noticed that the discussion list was seldom used, "out of well-known reasons (fear of having a personal opinion, different from the superior's opinion, communication inertia within the profession, the fear that another colleague might consider your question as stupid etc.)" Another important remark was that there were many passive members.

At the present the Biblos discussion list is in function. The archive and the information about the members can be found at the following link: http://apollo.bcu-iasi.ro/mailman/listinfo/biblos, but whilst the archive is available to the members, the list of members is available only to the list administrator.

For a new member to join the list, one has to send a message to an email address (biblosrequest@apollo.bcu-iasi.ro). After receiving confirmation, new members will receive all the messages addressed to the list. Members communicate with each other via email, and all the members receive the messages send to the email address biblos@bcu-iasi.ro.

Members' messages are issued and send as numbers of the discussion list's volume (as in the case of a printed magazine). Each day one or several numbers of the discussion list is being send via email to the members. Usually, members post topics of their immediate interest (professional questions mostly), and there are or there are not comments (replies) to their posts.

I have joined the Biblos discussion list on May $24^{\text {th }}, 2015$. My initial intention was to post the questions of my interview on Biblos discussion list.

I have joined the list declining my position (I am a librarian at the National Military Library, Bucharest), but I have not expressed my intention to conduct a netnographic research on their community.

My research is focused on receiving and analyzing the answers to my interview regarding project management in libraries. As a contingency plan in case I do not receive any answers, I shall focus on the presence of the project management terminology in the posts and on the interest manifested by the list members in the project management concept and methodologies.

Throughout my research I shall use the definition of the project as stated by the PMBok Guide: "A project is a temporary endeavor undertaken to create a unique product, service, or result".

I analyzed the content of the posts in search of finding one of the following key-words: project, project management, project manager, project management software, stakeholders, planning, initiation, project charter, work breakdown structure (or its acronym WBS), execution, monitoring, controlling, closing, evaluation, project cost, milestone, budget, Gantt chart, deliverables, evaluation.

\subsection{Results}

During the period from May $26^{\text {th }}$ and June $20^{\text {th }}, 2015$, there were 85 posts made by over 15 members. Two things must be noted: first of all, there are numbers that repeat themselves in the same day, and there are members who repeat their message posted in a previous number.

The topics covered professionally related issues. In Table 2 are listed the topics and the number of posts related to the respective topics.

My research was conducted during a month, and in that period some members proved to be more active than others. One of them has posted links to articles of professional interest. Others were 
deeply and personally involved in drawing attention to the irregularities of Romanian participation to Barcelona Seminar. This conference topic was covered by many numbers of the discussion list from June. The initial message drew the attention to the Romanian presentation of posters to the conference. The following messages could be considered as a conversation between that member and another one, but they are just replies, and not de facto comments to the initial post. Another post that inflated the members' reactions was the unsubscribe message posted by a member who denounced the "unprofessional" and "irreverent" attitude of another member, deciding therefore to leave the discussion list.

The members do not hide themselves under the umbrella of anonymity, but they give their full name, position and contact data.

The posts are written in professional jargon. The members use words such as institutional repository', 'bibliographical research', 'metadata', words which can be understood only by professional librarians.

\begin{tabular}{|c|c|c|}
\hline No. & Topic & $\begin{array}{l}\text { Number } \\
\text { of posts }\end{array}$ \\
\hline 1. & Various notices related to conferences, events & 23 \\
\hline 2. & Professional issues & 5 \\
\hline 3. & Metropolitan Library & 3 \\
\hline 4. & $\begin{array}{l}\text { Barcelona Seminar }\left(3^{\text {rd }} \text { International Seminar in LIS }\right. \\
\text { Education and Research organized by the Faculty of } \\
\text { Library and Information Science, University of } \\
\text { Barcelona, 4-5 June 2015) }\end{array}$ & 8 \\
\hline 5. & UDC Seminar & 2 \\
\hline 6. & Links to professional literature & 12 \\
\hline 7. & Library identity and vision & 5 \\
\hline 8. & UNIMARC & 1 \\
\hline 9. & Metadata & 1 \\
\hline 10. & Bibliography on indexing & 6 \\
\hline 11. & Interlibrary loan & 3 \\
\hline 12. & Legal deposit & 1 \\
\hline 13. & Institutional repository & 1 \\
\hline 14. & Unsubscribe message & 8 \\
\hline 15. & Project Management & 2 \\
\hline
\end{tabular}

Table 2. Topics and number of posts on Biblos discussion list (May $26^{\text {th }}$-June $20^{\text {th }}$, 2015)

There were no particular observable rituals or activities, nor was there noticed a relationship with other similar online groups.

From the interface point of view, the Biblos discussion list is not as friendly and attractive as other discussion forums or social media. There are some shortcomings which can be even considered obstacles and which can hinder someone in using the discussion list. One of the obstacles is the fact that one has to use an intermediary means (personal email address) in order to be able to take part in the discussions. Another shortcoming is the fact that some members use diacritical marks when writing their posts. However, these marks are not rendered as such making the message difficult to be read. 
To the purpose of my research for my thesis, I have found only two messages related to the topic of my interest. The first one represents a reference to organizational aspects related to a particular European funded project. The second message is my own message which included the request and the questions of the interview (which can be found in the previous chapter of this paper). Oddly, the two messages have been posted in the same day in two different issues of the discussion list, number 18 , respectively number 19 from June the $12^{\text {th }}$. I have not received any comments or responses to my message, neither to my questions.

\subsection{Discussion and conclusions}

The general impression confirms Dan Stoica's findings: even though the discussion list can be considered a proper forum for library professionals, it is not used at its full capacity, and it is not fully exploited. Doubtlessly, a research conducted over a longer period of time would reveal more interesting and pertinent data.

During a month, there were only two posts containing the word 'project'. It is hard to explain the lack of interest in project management among professionals who work in libraries which most likely have already implemented new services, whether they have called them projects or not.

It may look like the results of this research of the Biblos on line community could not be helpful for my thesis. However, the data is relevant because the messages posted on this discussion list could be considered to be a radiography of the professional community of Romanian librarians which rather contradicts the de facto character of inter-institutional collaboration.

It is strange that Romanian libraries, which use very structured tools for organizing information, are not fully aware of the power of another well-structured tool that is project management. Libraries do not have to reinvent the wheel, neither to create new departments or complex infrastructure for project management. They can build on the existing structure, they can tailor the existing and well-known project management methodologies, and they can even 'do more with less' (they can use the existing methodologies without investing in expensive project management software).

The study of the foreign literature on the topic of project management in libraries confirmed the concern towards this matter. The articles I read dealt with general issues regarding project management methodologies employed by various libraries, with case studies presentations which highlighted criteria of project success, or the reasons of failure, with presentations which outlined the advantages of using project management methodologies. Two common issues emerged from the literature. First of all, libraries need to change in order to remain competitive and visible. Then, project management is the proper instrument to manage change manifested in bold strategic initiatives.

The data obtained from my researches (the interview and the netnography) may have not answered the question formulated in the title of my thesis. However, the data revealed a certain status quo of the relationship the Romanian professional community has with project management culture. The interest in introducing and employing project management methodologies varies from library to library and from professionals to professionals. I can only assume that in the case of the libraries which already use project management methodologies, the interest is fostered by the top management. On the other hand, in the case of librarians who did not or would not answer my interview request, they are not encouraged by their top management to manifest interest in introducing project management methodologies.

My experiment (searching and gathering information on the topic solely from the Internet via Google search engine) turned out unsurprisingly all right. Libraries often take pride in holding the monopoly over "valuable", "authoritative" and "verified" information which passed by a rigorous publishing selection and which libraries offer free of charge. I have been able to find free of charge 
valuable, authoritative (heavily cited) and verified information on the Internet. The articles I have downloaded (conveniently for me), have cross-references among themselves or they refer to the same 'authoritative' bibliography.

My library does not stand a chance in the face of the ubiquity of the Internet unless it acknowledges this need for change.

Kotter considers that the initiative for change should come from the top management, that it should belong to the founders of an organization. In a library's case, as Vinopal (2012 p. 379) considers, "while some initiatives are conceived by upper-level management, service and workflow improvement projects are often initiated by the staff "in the trenches" who work most closely with users, see how they work, and hear their needs". Kotter (2000 p. 61) suggests that the second step of managing change implies "forming a powerful guiding coalition" around a transformational initiative. This can be a solution, although a popular saying suggests that the best way to burry an idea, is to set up a steering committee.

Auto-diagnosis or determining the maturity level can also be a starting point in order to identify strengths and weaknesses of project management in an organization. But this is the case of libraries which already use project management methodologies for managing their projects.

What is to do with libraries which are implementing strategic initiatives calling them projects because it is trendy, but ineffectively managing them? The solutions are not easy to find, and if found, they are not easy to adopt. From the top management perspective, libraries need to shift their management paradigm and adopt project management as an organizational strategy. However, my assumption is that the library staff from the middle management zone has a more powerful influence on adopting project management as strategy. As mentioned previously, libraries are collaborative institutions. The emergence of shared librarianship processes (such as cataloguing, classification or indexing documents) has freed the library staff from executing all these time consuming activities and has opened the possibility for this time to be consumed for implementing new initiatives. Although the informal conversations with Romanian professionals cannot be considered reliable information, the insights obtained can be of great value. If one reads between the lines, one can notice that the librarians (whose number increasingly decreases) feel overwhelmed by the new tasks - dealing with the projects without or with little or superficial training on the matter. It is at this level where the change needs to begin. The librarians involved in projects must acknowledge their lack of skills in project management and must request proper training. Moreover, as their foreign fellows, they can publish accounts on their project management experiences in specialized magazines or (especially) on online professional forums. Thus, they will help not only disseminate project management concepts, but also lay the foundation of a high performing project management community within library profession.

However, I must go beyond the mere disclosure of the status quo. My own library is rather invisible on the world wide information market, heavily affected by personnel and budgetary cuts, but it has unique, niche-type, potentialities. It comprises a generous collection of books regarding the memory of wars Romania has taken part of, books which are of great interest for researchers. The good news is that my library does not have to go through all the stages other libraries have gone over the last years, nor that it has to reinvent the wheel.

\section{Note}

[1] The initial and extended version of this paper was written in 2015 as my graduating thesis in order to obtain the master's degree in Project Management. Also, I intended to conduct an experiment, aiming to search and obtain all the needed information for this paper solely on Internet via Google search engine (except a handful of books from my private collection, from the collection of the library where I am employed and from the National Library's collection). 


\section{References}

Anzalone, F. M. (2000) Project Management: A Technique for Coping with Change, Law Library Journal, 92(1), pp. 1-18, available: http://aallnet.org/mm/Publications/llj/LLJ-Archives/Vol-92/ pub_1lj_v92n01/2000-4.pdf [accessed 11 November 2014].

Atkins, S. (2004) Projecting Success: Effective Project Management in Academic Libraries, Proceedings of the IATUL Conferences. Paper 1, pp. 1-11, available: http://docs.lib.purdue.edu/ iatul/2004/papers/1 [accessed 22 September 2014].

Babbie, E. (2011) The Basics of Social Research, $5^{\text {th }}$ ed., Wadsworth: Cengage Learning.

Barba, S. and Perrin, J. (2010) Great Expectations: How Digital Project Planning Fosters Collaboration between Academic Libraries and External Entities, The Unabashed Librarian, 155, pp. 18-22.

Bassett, C. and Kerns, R. (2013) The Project that Hurts Your Head: Simple Project Management for the Innovating Law Librarian, available: http://scholarship.law.missouri.edu/facpubs/505 [accessed 3 March 2015].

Biblioteca Națională a României (2014) Raportul de activitate pe anul 2013 [National Library of Romania. Activity Report 2013], available: http://www.bibnat.ro/dyn-doc/RAPORT\%202013\% 20varianta\%20finala.pdf [ accessed 28 April 2015].

Bonghez, S. (2013) Managementul proiectelor: adevăr sau provocare [Projects' Management: Truth or Dare], București: Universul Juridic.

Bonghez, S., Radu, L. and Grigoroiu, A. (2012) Implementing Project Management as a Business Development Strategy in Medium Sized Companies, available: http://www.pmarena.ro/wp-content/ uploads/2012/06/Implementing-Project-Management-as-a-Business-Development-Strategy-inMedium-Sized-Companies.pdf [accessed 9 September 2014].

Buschert, K., Ishida, M. and Tang, B. (2012) Multiple Project Management at Academic Libraries, available: https://doi.org/10.14288/1.0075712 [accessed 22 May 2015].

Cairns Libraries (2011) Cairns Libraries Strategic Business Plan 2011-2016, available: http:// www.cairns.qld.gov.au/data/assets/pdf file/0004/46723/Cairns-Libraries-Strategic-Business-Plan20112016.pdf [accessed 20 January 2017].

Cambridge University Library (2010) Working Together: a Strategic Framework, 2010-2013, available: http://www.lib.cam.ac.uk/strategic_framework.pdf [accessed 20 January 2017].

Coravu, R. and Stoica, D. (2002) Traiectorii profesionale [Professional Trajectories], Biblos, 13, pp. 36-38, available: http://www.bcu-iasi.ro/docs/biblos/biblos13/traiectorii.pdf [accessed 22 May 2015].

Drucker, P. F. (1986) Management: Tasks, Responsibilities, Practices, New York, available: http://www.slideshare.net/siddharthgtyagi/management-tasks-responsibilities-practices-by-peterdrucker [accessed 28 September 2014].

Frischer, B. (2005) The Ultimate Internet Café: Reflections of a Practicing Digital Humanist about Designing a Future for the Research Library in the Digital Age, Library as Place: Rethinking Roles, Rethinking Space, Washington: Council on Library and Information Resources, pp. 41-55, available: http://www.clir.org/pubs/reports/pub129/frischer.html [accessed 22 March 2015].

Gareis, R. (2006) Happy Projects, București: ASE.

Horwath, J. A. (2012) How Do We Manage? Project Management in Libraries: An Investigation, Partnership: The Canadian Journal of Library and Information Practice and Research 7(1), pp. 134, available: https://doi.org/10.21083/partnership.v7i1.1802 [accessed 12 February 2015]. 
IFLA Library Buildings and Equipment Section (2013) Questionnaire about library buildings, available: http://www.ifla.org/files/assets/library-buildings-and-equipment/Publications/

poe final_version.pdf [accessed 28 November 2014].

International Federation of Library Associations and Institutions (2001) The Public library service: IFLA/UNESCO guidelines for development, available: http://www.ifla.org/files/assets/hq/ publications/archive/the-public-library-service/publ97.pdf [accessed 8 December 2014].

Jochumsen, H., Skot-Hansen, D. and Rasmussen, C. (2012) The Four Spaces - a Model for the Public Library, New Library World, 113(11/12), pp. 586-597, available: https:// doi.org/10.1108/03074801211282948 [accessed 12 May 2014].

Kinkus, J. (2007) Project Management Skills: A Literature Review and Content Analysis of Librarian Position Announcements, College \& Research Libraries, 68(4), pp. 352-363, available: https://doi.org/10.5860/crl.68.4.352 [accessed 12 February 2015].

Kotter, J. (2000) Leading Change: Why Transformation Efforts Fail, On Point.

KPMG (2013) Project Management Survey Report, available: https://assets.kpmg.com/content/ dam/kpmg/pdf/2013/07/KPMG-Project-Management-Survey-2013.pdf [accessed 12 December 2014].

Kulavuz-Onal, D. and Vasquez, C. (2013) Reconceptualising Fieldwork in a Netnography of an Online Community of English Language Teachers, Ethnography and Education, 8(2), pp. 224238, available: https://doi.org/10.1080/17457823.2013.792511 [accessed 12 December 2014].

Laerkes, J. and Manolis, P. (2013) Building Libraries for Tomorrow: INELI Cohort 1 Collaborative Project Report, available: http://www.grlc.vic.gov.au/sites/default/files/pdfs/BoardReport-Attachment4-Sept-16-2013.pdf [accessed 12 October 2014].

Library of Congress (2010) Strategic Plan: Fiscal Years 2011-2016, available: http:// lcweb2.loc.gov/master/libn/about/documents/strategicplan2011-2016.pdf [accessed 24 April 2017].

Oracle (2009) Does Your Organization Need a Project Management Office? Improving project success rates with a PMO, available: http://www.oracle.com/oms/eppm/organization-need-pmowp-193596.pdf [accessed 22 May 2015].

Porter, M.E. (2008) The Five Competitive Forces that Shape Strategy, Harvard Business Review, 86(1), pp. 79-93.

Pulse of the Profession (2013), available: http://www.pmi.org/ /media/PDF/Business-Solutions/ PMI-Pulse\%20Report-2013Mar4.ashx [accessed 12 October 2014].

Rădoi, M. (2010) Strategie managerială: Biblioteca Centrală Universitară „,Carol I” din București: 2011-2015 [Managerial Strategy: „Carol I” Central University Library of Bucharest: 2011-2015], available: http://bit.ly/2vW6Oqb [accessed 22 May 2015].

Stanley, T., Norton, F. and Dickson, B. (2003) Library Project Management in a Collaborative Web-based Working Environment, The New Review of Academic Librarianship, 9(1), pp. 70-83, available: https://doi.org/10.1080/13614530410001692040 [accessed 20 September 2014].

State Library of New South Wales (2012) People places: a guide for public library buildings in New South Wales, $3^{\text {rd }}$ ed., Sydney: State Library of NSW, available: www.sl.nsw.gov.au/services/ public libraries/docs/people places.pdf [accessed 12 October 2014].

Stueart, R. and Moran, B. (2007) Library and Information Center Management, $7^{\text {th }}$ ed., London: Libraries Unlimited.

Turner, J. R. and Simister, S.J. (2004) Manual Gower de management de proiect [Gower Handbook of Project Management], București: Codecs. 
Vinopal, J. (2012) Project Portfolio Management for Academic Libraries: A Gentle Introduction, College and Research Libraries, 73(4), pp. 379-389 available: https://doi.org/10.5860/crl-277 [accessed 18 October 2014].

Whitaker, S. (2012) The Art Of Tailoring: Making Your Project Management Methodology Fit, available: http://www.pmi.org/ /media/PDF/learning/benefits-of-tailoring.ashx [accessed 9 August 2014].

Zarinpoush, F. (2006) Project Evaluation Guide for Nonprofit Organizations, Toronto: Imagine Canada, available: sectorsource.ca/files/resources/files [accessed 22 March 2014].

Zwaard, K. and Brunton D. (2014) Managing a Library of Congress Worth of Data, March 28, 2014, available: http://blogs.loc.gov/digitalpreservation/2014/03/managing-a-library-of-congressworth-of-data/ [accessed 25 February 2015]. 